\title{
IMPROVING STUDENTS' SPEAKING ABILITY ON EXPRESSING PLAN THROUGH PROBLEM BASED LEARNING (PBL) METHOD
}

\author{
Dinar Vincy Yunitaka Bahrudin \\ (Madura Islamic University/dinarvincy@yahoo.co.id)
}

\begin{abstract}
Tenth-grade students at SMAN 4 Pamekasan faced some problems in speaking. They are difficult to express their ideas in oral form and unconfident when they speak English. It happens because of limitation on vocabulary, and they may never practice speaking. Problem Based Learning (PBL) is a good method to teach Speaking. This research is a Classroom Action Research (CAR). The subject is the 37 students of Tenth-grade students at SMAN 4 Pamekasan. There are two cycles, one meeting in each cycle. The research procedures consist of planning, acting, observing, and reflecting. Field note, observation, documentation, and test were used to collect the data. The result revealed mean scores of preliminary study were 54.46 and the percentage score was $24.32 \%$. The mean score of the test of cycle 1 was 67.84 and the percentage score was $48.64 \%$. The mean score of class in speaking test gained until 80.27 and the percentage score was $86.48 \%$. The improvement of the percentage score students who got equal or greater than KKM from cycle I to cycle II was $37.84 \%$. It concludes that Problem Based Learning Method can improve students' speaking ability on Expressing Plan of the Tenth Grade at SMAN 4 Pamekasan.
\end{abstract}

Keywords:

Speaking Ability; Expressing Plan; Problem Based Learning

DOI: $10.19105 /$ ojbs.v12i2.2086

\section{A. Introduction}

In globalization era, English has become International Language in the world because English used to communicate with others people who have different Languages. Harmer states that English is an International Language that it is the most widespread medium of international communication. ${ }^{1}$ Many language learners regard speaking ability as the measure of knowing a language. That is why the main purpose

1 Jeremy Harmer, The Practice of English Language Teaching, 4th ed. (New York: Pearson Longman, 2007), 13. of language learning is to develop proficiency in speaking and communicative efficiency. They regard speaking as the most important skill they can acquire and assess their progress in terms of their accomplishments in spoken communication. Meanwhile, the Tenth grade of students at SMAN 4 Pamekasan also faced some problems in learning Speaking. The first problem is the students difficult to express their ideas in oral form. It happens because students have not mastered much vocabulary. The second problem is the 
students are not confident when speaking English with his friends.

Therefore, the teaching and learning process need a good method or a good ways to solve student's problems and motivate the students and increase their curiosity particularly in speaking ability. One of the ways to improve or develop their speaking is using Problem Based Learning (PBL) method. Problem Based Learning (PBL) is a group of teaching learning process that is focused to the process of problem solving which is faced in the class. Barrow as quoted by Huda also states that Problem Based Learning (PBL) is learning gained through a process towards understanding the revolution of a problem whose outcomes and learning process are directed to knowledge and solving a problem. $^{2}$ The purpose of Problem Based Learning (PBL) according to Suprijono is to develop the skills of learners to learn independently, develop research skills and problem solving skills, and shape behavior and social skills. ${ }^{3}$

The Problem Based Learning (PBL) components according to Rayne and Symons (in Journal of English Language Teaching, 2014:52) have four components, one of which the researcher chooses the Group Work component. Group work is students work

2 M. Huda, Model-Model Pengajaran Dan Pembelajaran Isu-Isu Metodis Dan Paradigmatis (Yogyakarta: Pustaka Pelajar, 2013).

3 Agus Suprijono, Cooperative Learning Teori Dan Aplikasi PAIKEM (Yogyakarta: Pustaka Pelajar, 2013). together in small groups and provide a framework in which students can test and develop their level of understanding of the material. So, Problem Based Learning (PBL) can help students in solving the problem that they often faced in speaking. They will solve the problem together in their group and discuss each other so that their ideas and information can develop.

Based on the background of study above, the researcher want to mention the implementation of Problem Based Learning ( $\mathrm{PBL}$ ) method in improve students' speaking ability on expressing plan and to know whether the using of Problem Based Learning (PBL) method in improve students' speaking ability on expressing plan of the Tenth grade at SMAN 4 Pamekasan.

\section{B. Method}

This research is conducted through Classroom Action Research (CAR) method. Stephen Kemmis (adapted Hopkins) stated that "action research is a form of self-reflective enquiry undertaken by participants in social (including educational) situations in order to improve the rationality and justice of their own social or educational practice, their understanding of these practices, and the situations in which the practices are carried out". ${ }^{4}$

This research is Classroom Action Research that deals with the using of Problem Based Learning (PBL) Method

\footnotetext{
4 D Hopkins, A Teacher's Guide to Classroom Research (England: McGraw-Hill, 2008).
} 
to improve students' speaking ability on Expressing Plan of the Tenth Grade at SMAN 4 Pamekasan. This research is implemented in the form of collaborative action research and conducted collaboratively with the headmaster, the English teacher, and the students of the Tenth Grade at SMAN 4 Pamekasan. Linda Ross (adapted by Burns) states that "Collaborative action research is a powerful form of staff development because it is practice to theory rather than theory to practice. ${ }^{5}$ Teachers are encouraged to reach their own solutions and conclusions and this is far more attractive and has more impact than being presented with ideals which cannot be attained".

The research is conducted by following the procedure of the Classroom Action Research (CAR). It is composed of two cycle to identify all fact including the succes and failure of the action, it means whether the action should be continue and revise or stop. Based on the procedures above the research is start of planning, acting, observing and reflecting. Below will be described the research procedures according to Kemmis and Mc Taggart (adapted by Hopkins). ${ }^{6}$ The researcher infers that based on the curriculum that is used in SMAN 4 Pamekasan, the standard Minimum Achievement (KKM) is 75 . Therefore, this research will regard

\footnotetext{
${ }^{5}$ Anne Burns, Collaborative Action Research for English Language Teachers (New York: Cambridge University Press, 1999).

6 Hopkins, A Teacher's Guide to Classroom Research.
}

to be successful if the $80 \%$ of the research's subjects under study can pass the minimum score which has been stated above.

The research is conducted by following the procedure of the Classroom Action Research (CAR). It is composed of two cycle to identify all fact including the success and failure of the action, it means whether the action should be continue and revise or stop. Based on the procedures above the research is start of planning, acting, observing and reflecting. Below will be described the research procedures according to Kemmis and Mc Taggart (adapted Hopkins). ${ }^{7}$

The first is Planning is the first step of action research. Planning is made after researcher does the preliminary study. The teacher and the researcher play the cycle that will be given to the students in the class. It is aimed to implement method that used by the researcher in class. The researcher also makes lesson plan, format of observation of the lesson plan, prepare the scoring sheet and field note that will be used while the observation conducted. Furthermore, the researcher and the teacher decide to choose the topic for teaching.

The second is Acting means instructional activities done by researcher and the students in the class based on the planning that has been made before or the implementation of

\footnotetext{
${ }^{7}$ Hopkins.
} 
planning. The instructional activities used Problem Based Learning (PBL) done for each cycle. It will be explained more in the next sub title.

The third is observing, it is conducted during action given to the students. Observation is done by making field notes. The researcher goes around each group to observe the activity in the class. The researcher will share about the strength and weakness during the process. Besides, the researcher will discuss to the teacher in order to improve teaching and learning process in the next cycle.

The fourth is reflecting, it is conducted by the researcher and the teacher to evaluate acting and the students' progress in learning process. The reflection result is used to find out some weaknesses have to be revised and the revisions are aimed to improve teaching and learning process in next cycle.

\section{Data Collection Procedures}

Data collection is how the researcher collects the data from the students who have conducting a teaching and learning process. Collecting data is very needed by researcher to know the students' improvement by joining this research. To collect the data, the instruments were used to gather the data by the researcher. The data of this research consisted of field note, observation, test, and documentation.

\section{a. Field Notes}

Field note is used to collecting data related to situation of class (subject) gotten in teaching learning process from cycle I and cycle II go on. This data is used to the improvement of learning the next cycle.

\section{b. Observation}

Observe is looking at an occurrence, movement and process. Observing is not an easy task since people are influenced a lot by interests and tendencies they have. In observation the most effective method is by fulfilling an observation blank form as a tool. The arranged form consists of items about occurrences or behaviors that drawn will be happened Arikunto. ${ }^{8}$

In this stage the researcher used field note and camera for taking the picture which is used to observe and to know the situation and activities during teaching-learning process. By used field note and camera the writer would like to know the class situation and participation of students.

\section{c. Test}

Test according to Arikunto is used to measure the students' basic ability and achievement. To get the data the researcher did the

\footnotetext{
${ }^{8}$ Suharsimi Arikunto, Prosedur Penelitian Suatu Pendekatan Praktek (Jakarta: Rineka Cipta, 2013).
} 
test that consists of pre-test and post-test. $^{9}$

The function of pre-test is to know how far the using of Problem Based Learning (PBL) method improves students' speaking ability before they use. While, the function of post-test is to know the increasing of speaking skill after they use Problem Based Learning (PBL) method. Pre and post-test are to know the differences of the students' speaking ability before and after the teaching by using the method.

\section{d. Documentation}

Arikunto states that documentation methods is an activity to look for variable like notes, transcribes, books, newspapers, magazines, etc. ${ }^{10}$ This method is not too difficult since if there is an error the source data is still not change.

The criteria of success are emphasized on the process and the product of teaching learning activities. This study is called successful if $80 \%$ of students achieve the score equal as the KKM. If the study hasn't met the criteria, it's called not successful and need improvement to meet the targets. Analysis of data used in this research to know the improving of students' speaking ability by using Problem Based Learning method with the average student's scores and
Percentage of the criteria of success the researcher used formula:

a. The result of individual score

$$
\text { score }=\frac{\text { Total Score }}{\text { Maximal Score }} X 100
$$

b. The average students scores the researcher used formula

$$
M=\sum \frac{\times}{N}
$$

$$
\begin{aligned}
\mathrm{M} & =\text { Mean } \\
\Sigma \mathrm{x} & =\text { Individual Score } \\
\mathrm{N} & =\text { Number of Students }
\end{aligned}
$$

c. The Percentage of the criteria of success the researcher used formula

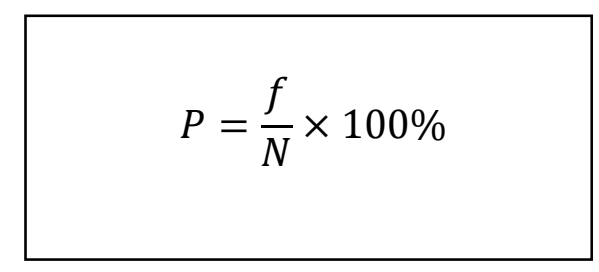

$$
\begin{aligned}
P= & \text { Percentage mastery of } \\
& \text { student learning } \\
f= & \text { Number of students who } \\
& \text { complete learning } \\
N= & \text { Total number of students }
\end{aligned}
$$

\section{Results}

\section{Result of Preliminary Study}

The first step is to get the mean score of the class in preliminary study, it is calculated as following:

\footnotetext{
${ }^{9}$ Arikunto.

${ }^{10}$ Arikunto.
} 


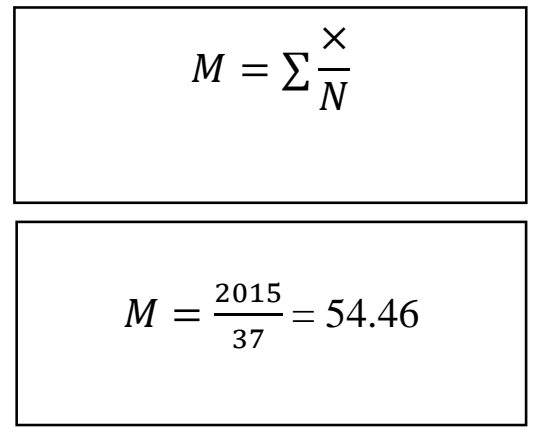

Based on the result of preliminary study, the data showed that the mean score of the test of preliminary study was 54.46 .

The second step is to get the percentage students score of the class in preliminary study, it is calculated as following:

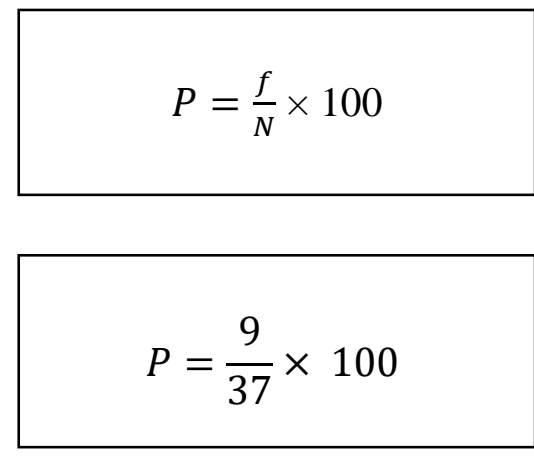

The result of the preliminary study, the data showed that the percentage student of the test of preliminary study was $24.32 \%$.

\section{Result of Cycle 1}

The first step is to get the mean score of the class in cycle $\mathrm{I}$, it is calculated as following:

$$
M=\sum \frac{\times}{N}
$$

$$
M=\frac{2510}{37}=67.84
$$

Based on the result of the cycle I, the data showed that the mean score of the test of cycle I was 67.84. The second step is to get the percentage students score of the class in cycle I, it is calculated as following:

$$
P=\frac{f}{N} \times 100
$$

$$
P=\frac{18}{37} \times 100=48.64 \%
$$

The result of the cycle I, the data showed that the percentage students of the test of cycle I was $48.64 \%$. Based on the result test of the cycle 1 , the data showed that the mean score of the test of cycle 1 was 67.84 and the percentage of students was $48.64 \%$. There were 18 students of 37 students who passed the Criteria Minimum Score-Kriteria Ketuntasan Minimum (KKM) 75 and there are 19 students of 37 students did not pass that criterion.

\section{Result of Cycle 2}

The first step is to get the mean score of the class in cycle $\mathrm{II}$, it is calculated as following:

\begin{tabular}{c|}
\hline$M=\sum \frac{\times}{N}$ \\
\hline$M=\frac{2970}{37}=80.27$ \\
\hline
\end{tabular}


Based on the result of the cycle II, the data showed that the mean score of the test of cycle II was 80.27. The second step is to get the percentage students score of the class in cycle $\mathrm{II}$, it is calculated as following:

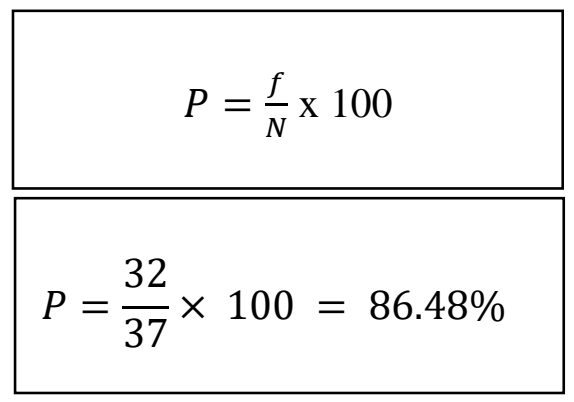

The result of the cycle II, the data showed that the percentage of the students of the test of cycle II was $86.48 \%$.

The first result test of preliminary study, the data showed that the mean score of the test of preliminary study there were only 9 Students who derived the score above the Criteria Minimum Score-Kriteria Ketuntasan Minimum (KKM) or passing grade. Meanwhile, the other 28 Students were below that criterion. From the data above, the students who pass Criteria Minimum Score-Kriteria Ketuntasan Minimum (KKM) 75 are 9 students of 37 students. The average scores was 54.46 and The Percentage score was $24.32 \%$.

The second result test of the cycle I, the data showed that the mean score of the test of cycle I was 67.84 and the percentage of students was $48.64 \%$. There were 18 students who passed the Criteria Minimum Score-Kriteria
Ketuntasan Minimum (KKM) 75 and there are 19 students did not pass that criterion.

The third result test of cycle II, the mean score of class in speaking test gained until 80.27 and The Percentage score was $86.48 \%$. There was 32 students who passed the Criteria Minimum Score-Kriteria Ketuntasan Minimum (KKM) 75 and there are 5 students did not pass that criterion.

There was a slight improvement of students percentage score from the students reading on the preliminary study to the students speaking on cycle I and cycle II. The data of preliminary study showed that the percentage score was $24.32 \%$ and the percentage score of the students speaking on the first cycle was $48.64 \%$ and the second cycle there was $86.48 \%$ of percentage score improvement.

Teaching learning process in this cycle was better and the researcher found that students enjoyed the activity. The improvement of the percentage score students who got equal or greater than KKM from cycle I into cycle II was $37.84 \%$. Therefore, the researcher felt that the using of Problem Based Learning (PBL) method to improve students' speaking ability on expressing plan at the Tenth grade of SMAN 4 Pamekasan was successful because the percentage score of the students speaking was $86.48 \%$. While, based on criteria of success in this research was $80 \%$ of students achieve score equal or greater than KKM. 


\section{Conclusion}

The research conclusion is presented based on the result of data analysis, the researcher inferred that teaching using Problem Based Learning (PBL) method is effective and can improve students' speaking ability. It can be proved through several data such as: observation result which shows students' enthusiastic and participative the learning process actively. They were also motivating the students in learning speaking and reduce the hesitation in practicing their speaking.

In preliminary study the students' average score was 54.46, than the researcher concludes that there were only $24.32 \%$ of students pass the KKM. In the cycle I, the student's average score was 67.84 and there were $48.64 \%$ could pass the KKM. In the cycle II the students got average score 80.27 , and the students pass KKM were 32 students, it means that $86.48 \%$ of the students pass the KKM. From the result above it can be concluded that use of
Problem Based Learning (PBL) method could improve students' speaking ability.

\section{References}

Arikunto, Suharsimi. Prosedur Penelitian Suatu Pendekatan Praktek. Jakarta: Rineka Cipta, 2013.

Burns, Anne. Collaborative Action Research for English Language Teachers. New York: Cambridge University Press, 1999.

Harmer, Jeremy. The Practice of English Language Teaching. 4th ed. New York: Pearson Longman, 2007.

Hopkins, D. A Teacher's Guide to Classroom Research. England: McGraw-Hill, 2008.

Huda, M. Model-Model Pengajaran Dan Pembelajaran Isu-Isu Metodis Dan Paradigmatis. Yogyakarta: Pustaka Pelajar, 2013.

Suprijono, Agus. Cooperative Learning Teori Dan Aplikasi PAIKEM. Yogyakarta: Pustaka Pelajar, 2013. 